\title{
Ace of Aces: Erich Hartmann the Blond Knight of Germany
}

\author{
Dr. C. Hind, Prof. A. Nicolaides \\ Graduate School of Business Leadership, University of South Africa, Midrand, South Africa \\ Email:nicola@unisa.ac.za
}

How to cite this paper: Hind, C., \& Nicolaides, A. (2020). Ace of Aces: Erich Hartmann the Blond Knight of Germany. Open Journal of Social Sciences, 8, 383-406. https://doi.org/10.4236/jss.2020.83034

Received: October 29, 2019

Accepted: March 24, 2020

Published: March 27, 2020

Copyright $\odot 2020$ by author(s) and Scientific Research Publishing Inc. This work is licensed under the Creative Commons Attribution-NonCommercial International License (CC BY-NC 4.0). http://creativecommons.org/licenses/by-nc/4.0/

\begin{abstract}
History has seen numerous great aviators and specifically ace fighter pilots. None of them, however, comes close to the exceptionally gifted Erich Hartmann who served mainly on the Eastern Front during World War II. He was the top scoring fighter pilot of all the fighters in World War 2. He flew a staggering 825 missions in recording 352 victories (See Annexure 1). All the victories were recorded on the Eastern Front. "The Black Devil" as Hartmann was known, holds a record that has never been broken, and owing to the nature of modern aerial warfare it is unlikely to ever be broken. During the last years of the war, his repute had grown so colossal that when many Soviet pilots observed his Messerschmitt Bf 109 approaching, they would bolt instead of engaging him in aerial combat. This article provides a synthesized look at this talented contributor to World War II and aviation history in general. This study gives a brief overview of the Hartmann and his exploits during World War Two and was based on a literature study.
\end{abstract}

\section{Keywords}

Ace Pilot, Messerschmitt Aircraft, Luftwaffe, Aerial Combat Tactics, Flying Excellence

\section{Introduction and Background}

This article presents a synthesis of the literature describing the aviation career of Erich Hartman. Included literature provides context around and details about Hartman's achievements as an aviator, more specifically the combats that he was involved in and the machines he flew and took down. In Wolfe's (2001) book, "The Right Stuff", fighter pilots are described as having some interesting traits and Hartmann was no different. He was enormously confident, self-confident, and clearly had a superior cognitive ability and an almost natural ability to fly. 
Above all his love of aviation and flying was evident from an early age. He relished the challenges posed by aerial combat and was a very competitive individual with a desire to always be where the action was taking place, and in the heart of all aviation things. Hartmann was a diligent and loyal servant of the Luftwaffe.

During the Second World War, there were numerous fighter aircraft of outstanding quality, but none could match the German Luftwaffe's main single-engine, single-seat fighter, the famous Messerschmitt Bf 109. By late 1940, various Luftwaffe fighter units were being re-equipped with the daunting new $\mathrm{Bf}$ 109F-1 and F-2 Messerschmitt variants which had superior performance. Some of the notable German pilots including ace pilot Adolf Galland embraced the Bf 109 as a super plane which was able to outturn the British Supermarine Spitfire, and this was mainly because untried British pilots did not turn as closely as was possible due to their fear of falling into a high-speed stall (Sims, 1972; Green, 1980). Luftwaffe pilots considered the F-1s and F-2s to be exceptional planes which could effortlessly outclass the Spitfire Mk Is and IIs and they closely matched the Mk Vs which were almost ready to enter service. There were some who believed that the Spitfire had a higher rate of turn and a smaller turning circle (Spick, 1983) than the Messerschmitt, but this did not dent the reputation of the latter.

In general terms, the Messerschmitt and Spitfire aircraft were well matched in performance (Caldwell, 1991) and the consequence of an aerial duel was mainly finalized by the quality of the aviator, superior flying tactics, the relative position and the skill level of the opposite pilot (Price, 1995, 1991). RAF fighter pilots usually flew in tight, vee-shaped sections of three aircraft (Delve, 2007) which meant that the pilots were obliged to concentrate on observing each other's positions, rather than being free to keep a necessary vantage point in order to see adversarial aircraft (Duncan Smith, 1981; Bungay, 2000). In addition, "Fighting Area Tactics" also specified that RAF fighter pilots had to open fire on enemy aircraft at long-range, usually from about 275 to $370 \mathrm{~m}$, and then they were to break off without closing in on their prey (Bungay, 2000; Delve, 2007).

\section{Superior Luftwaffe Tactics}

Luftwaffe fighter pilots flew meticulously designed combat formations and employed the basic unit of a pair (Rotte) of fighters that would be widely spread out by about two hundred meters or so (Sims, 1972). The flight leader was followed to starboard and also to the rear by his wingman, who was competent enough to stay with him at all times. The leader could hunt enemy aircraft, and also cover the wingman's blind spots. The wingman could focus on searching the airspace in the leader's blind spots, both from behind and below (Green, 1980). It was common practice for a Schwarm to develop which included two sections teaming up in flight thus affording the pilots the opportunity to observe their surroundings more efficiently as they flew four abreast (Mason, 1973). They were 
also more difficult to sight than the RAF vee formation and pilots could manouevre their planes far more easily and climbing or descending was not all problematic. Schwarm formations allowed pilots to attack in efficient pairs. By contrast, the British vee formations placed planes in very susceptible positions (Bader, 2004). Luftwaffe fighter units flew as a Staffel or squadron, in which case three Schwarme were usually staggered in height and could defend each other easily.

\section{Ace Pilots}

"Aces" were pilots who were courageous fighter pilots who were officially credited with five or more "kills". In the Royal Air Force the concept was not fully recognized and the pilots never really accepted the concept of what an "ace" is. This was likely due to the fact that numerous good pilots never became aces. This was due to a lack of opportunities or sheer circumstance, or because they were killed or severely injured before they could accumulate relatively high "kill" scores. The Soviet Air Forces had the top Allied pilots in terms of aerial triumphs. Ivan Kozhedub was credited with 66 "kills" victories. The German Airforce utilized the notion of "one pilot, one kill", and ace pilots were known as Experten (Schneekluth, 1953). There were over 1000 aces, of whom at least 40 were South Africans (Tidy, 1968). British pilots and essentially most Allied pilots were by comparison not as well trained as Luftwaffe pilots (Shores, 1983). The German pilots tended to fly far more individual sorties and basically kept on flying until they were captured, severely wounded or killed in aerial combat.

Once a fighter pilot destroyed aircraft in air-to-air combat sorties in conjunction with other fighter pilots, each pilot was typically credited with his portion. Thus, if three pilots shared a "kill" each pilot would be attributed with one-third of a "kill". Assuming a pilot had the essential skills and the right aircraft, an element of luck always existed to place the right pilot in the right place at the right time (Tidy, 1968). Tactics however also played a key part in any aerial encounter between adversaries. Pilots like the renowned South African "Sailor" Malan were influential in developing many improved tactics for the RAF fighter pilots (Franks, 1994).

Tidy (citing Shores and Williams, 1966) asserted that there are three distinct classes of ace, although most of them combined aspects defining each individual type of each kind.

“...(1) The Defensive Ace: that is, the pilot flying over his own country or lines, in an effort to prevent the enemy from attaining air superiority. South Africans Tom Pattle and "Sailor" Malan (with 41 and 35 kills respectively) were the supreme examples of this type of ace, and finished first and third in the grand list of all Commonwealth aces. (2) The Offensive Ace: the pilot flying into the enemy's lines to seek out and destroy him, in an effort to attain air superiority. "Johnny" Johnson was the supreme example of this type and finished second overall (between Tom Pattle and "Sailor" Malan) with 38. (3) The Night Fighter Ace: unlike the other two (although "Sailor" Ma- 
lan shot down two enemy aircraft in one night in an individual "hate effort"), he had to fly alone, rather than in a pack, and had to proceed with infinite patience and caution in order to find his prey. John Cunningham was the most successful in this category with 20 kills...” (Tidy, 1968).

During the course of World War II, the ace pilots claimed approximately over 60 percent of all confirmed aerial combat successes, though during the early years of the war this percentage was significantly higher. The most successful RAF pilots were Polish pilots who had been trained by their air force to fly in loose formations and open fire on enemy aircraft from close-range. The Polish Air Force first struggled in the 1939 Invasion of Poland. Although they were pointedly outnumbered and with their aircraft, they were at times outmatched by more innovative German planes (Donald, 2000). Despite this, Polish pilots inflicted substantial damage on the Luftwaffe, shooting down 285 German aircraft for the loss of 333 Polish planes (Zaloga, 2004). Interestingly, Polish pilots, comprised $5 \%$ of the pilots who were active during the Battle of Britain, and were accountable for $12 \%$ of the total victories in that Battle.

On 11 June 1940, the Polish Government in Exile engaged in an agreement with the British Government to establish a Polish Army and Polish Air Force in the United Kingdom. Ten Polish fighter squadrons went into action in August 1940 and four Polish squadrons participated in the Battle of Britain with 89 Polish pilots involved. All in all, 145 Polish pilots defended British skies. Polish pilots were among the most experienced in the battle, due to their flying style and in any case, most of them having already fought during the 1939 blitzkrieg in Poland and the 1940 Battle of France (Cynk, 1998).

The Messerschmitt as depicted in Figure 1 above is together with its famous pilot, and focus of this article is responsible for the most air kills during World War II. Table 1 below provides a complete list of the top-ranking aces of World War II according to their number of kills. The particular aircrafts that were flown in during the kills are also detailed.

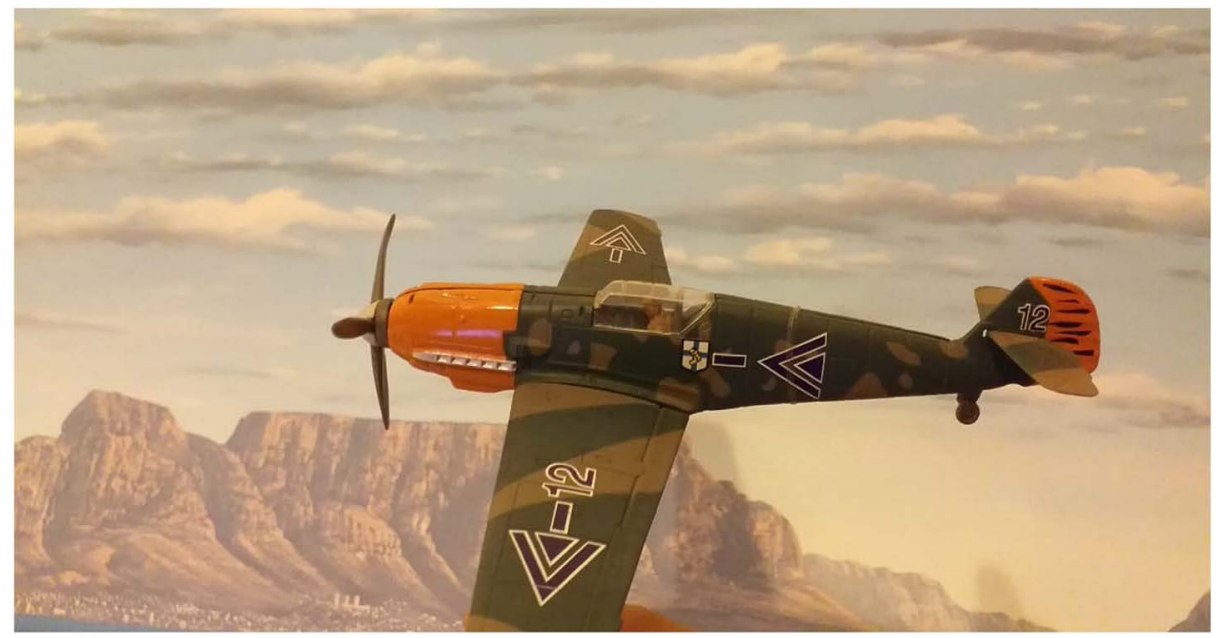

Figure 1. A model of the Messerschmitt Bf 109. Source: Author's own. 
Table 1. A selection of the greatest fighter aces of World War II.

\begin{tabular}{|c|c|c|c|}
\hline Name of Ace Pilot & Country & Aircraft flown & $\begin{array}{l}\text { Number of } \\
\text { "kills" }\end{array}$ \\
\hline Erich Hartmann & Germany & Messerschmitt Bf-109E & 352 \\
\hline Gerhard Barkhorn & Germany & Bf-109E, Bf-109G, Fw-190D-9 & 301 \\
\hline Günther Rall & Germany & Bf-109 & 275 \\
\hline Walter Nowotny & Germany & Bf-109E, Fw-190, Me-262 & 258 \\
\hline Erich Rudorffer & Germany & Bf-109E, Fw-190 & 222 \\
\hline Hans-Joachim Marseille & Germany & Bf-109E, Bf-109F & 158 \\
\hline Adolf Galland & Germany & Hs-123, Bf-109E, F-190, Me-262 & 104 \\
\hline Alexander Pokryshkin & Soviet Union & MiG-3, Yak-1, P-39, P-63 & 88 \\
\hline Hiroyoshi Nishizawa & Japan & A6M Zero & 87 \\
\hline Hans Wind & Finland & B239, Bf-109G & 75 \\
\hline Ivan Kozhedub & Soviet Union & $\mathrm{La}-5, \mathrm{La}-7$ & 66 \\
\hline Saburō Sakai & Japan & A6M2 Zero & 64 \\
\hline Marmaduke Pattle & Commonwealth & Gladiator, Hurricane & 50 \\
\hline Mato Dukovac & Croatia & Bf- 109 & 44 \\
\hline Constantin Cantacuzino & Romania & Bf-109G & 43 \\
\hline Tom Pattle & South Africa & SupermarineSpitfire & 41 \\
\hline Richard Bong & USA & P-38 Lightning & 40 \\
\hline Thomas McGuire & USA & P-38 Lightning & 38 \\
\hline A.G. "Sailor" Malan & South Africa & Supermarine Spitfire & 35 \\
\hline David McCampbell & USA & F6F Hellcat & 34 \\
\hline Frank Carey & Britain & Hawker Hurricane & 28 \\
\hline Geoffrey Allard & Britain & Hawker Hurricane, & 24 \\
\hline J.J. “Chris” Le Roux & South Africa & Supermarine Spitfire & 23.5 \\
\hline Douglas Bader & Britain & Supermarine Spitfire & 22 \\
\hline P.H. "Dutch" Hugo & South Africa & Supermarine Spitfire & 22 \\
\hline Lilya Litviak $^{\star}$ & Soviet Union & Yak-1 & 12 \\
\hline
\end{tabular}

Female ace pilot ${ }^{\star}$. Sources: (https://www.ranker.com/list/greatest-fighter-aces-for-all-time/polar-bear \& Tidy, 1968).

\section{Erich Hartmann-The Blond Knight of Germany}

Erich Hartmann was born in Weissach, in the Weimar Republic of Germany, on April 19, 1922, and had his mother as a role model aviator. In fact, his mother Elisabeth became one of Germany's first female glider pilots. He was so enamoured by her flying prowess that at the tender age of 15 , he was driven to receive his glider pilot's license. In 1939, aged only 18, Hartmann received his pilot's license enabling him to fly powered aircraft and so he began to undergo fighter pilot training and for two years trained on a superb plane, namely the 
dependable and prevailing fighter aircraft, the Messerschmitt Bf 109 which was the backbone of the German Luftwaffe (Bell, 2017). He developed combat techniques and superb gunnery skills. His advanced pilot training was completed on 31 January 1942, and, from 1 March 1942 to 20 August 1942, he learned to fly the Messerschmitt Bf 109 at the Jagdfliegerschule 2 (Mitcham, 2012).

Hartmann was soon dispatched to the veteran Jagdgeschwader 52 (JG 52) on the Eastern Front and his base of operations was situated in Maykop, Russia. This was near the north-eastern shore of the Black Sea. While he was there he was privileged to be placed under the direction of some of the Luftwaffe's most practiced fighter pilots. Hartmann and some other pilots were originally given the mission of ferrying Junkers Ju 87 Stukas to Mariupol. His primary flight ended with brake failure, and his Stuka crashed into the controller's cabin and devastated it (Kaplan, 2007). He was then allocated to III./JG 52, under the command of Gruppenkommandeur Major Hubertus von Bonin, and placed under the veteran flier Oberfeldwebel Edmund "Paule" Roßmann. He had the opportunity to fly alongside highly skilled pilots such as Hans Dammers and others, and he learned much from them and gradually perfected his combat strategies and developed an excellent reputation as a pilot with “...excellent eyesight, lightning-fast reflexes, great flying instincts, and an uncanny ability to stay cool in combat put him in harm's way time and again. But it was worth it: Hartmann proved to be a formidable flyer" (DeLong, 2018).

\section{A highly Efficient Predator}

Hartmann became (see Figure 2) the ultimate and leading exponent of the stalk-and-ambush tactics and he favoured the tactic of ambushing enemy aircraft and firing at them from very close range, about $20 \mathrm{~m}$, rather than becoming

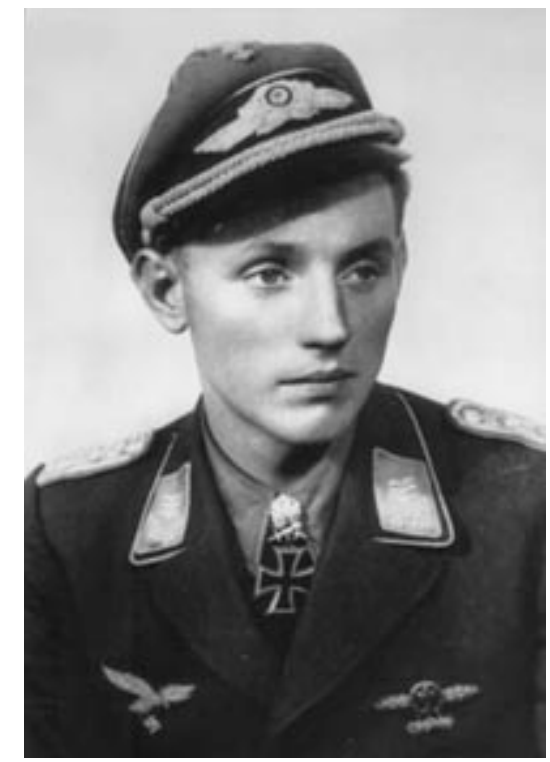

Source: https://www.luftwaffe.cz/hartmann.html.

Figure 2. Major Erich Hartmann. 
involved in challenging and unnecessary dogfights (Spick, 1996). He learned this tactic from one of his prior commanders, Walter Krupinski. It was a formidable tactic in which he flew in such a manner as to only expose his position relative to an enemy plane at the very last moment and then blaze away at them with his Messerschmitt's high-velocity $20 \mathrm{~mm}$ MG 151 cannon. He always sought to destroy an enemy plane with the least amount of ammunition and essentially gave the enemy pilot no time to respond by taking any kind of evasive action (Spick, 1996). Hartmann explained his assessment of adversaries:

"I knew that if an enemy pilot started firing early, well outside the maximum effective range of his guns, then he was an easy kill. But, if a pilot closed in and held his fire, and seemed to be watching the situation, then you knew that an experienced pilot was on you. Also, I developed different tactics for various conditions, such as always turning into the guns of an approaching enemy, or rolling into a negative $G$ dive forcing him to follow or break off, then rolling out and sometimes reducing airspeed to allow him to over commit. That was when you took advantage of his failing." (Final Interview with Erich Hartmann).

Hartmann described his method as "See-Decide-Attack-Reverse". He thus sought to always detect the enemy, then resolve how to continue with the attack, and finally attack at high speed and disengage to re-evaluate the situation (Patton, 1991). Most of his kills were thus based on firing on enemy planes from the rear and then immediately breaking off his attack (Rall, 2007). He permitted himself to get close enough to an enemy aircraft and then fire off rounds and maneuver away rapidly before the enemy could smash into his plane. He thus contrasted with the likes of Hans-Joachim Marseille (see Table 1), who was an amazing pilot and marksman and the master in the practice of the art of ricochet shooting who shot down 158 enemy aircraft.

He described his favourite method of attack in his last interview as follows:

"Coming out of the sun and getting close; dog-fighting was a waste of time.

The hit and run with the element of surprise served me well, as with most of the high scoring pilots. Once a Russian was shot down, especially the leader they became disorganized and easy to attack. This was not always the case, especially later in the war, and there were special units of highly skilled and disciplined pilots, such as the Red Banner units who would make life difficult" (Final Interview with Erich Hartmann).

Hartmann flew his primary combat mission on 14 October 1942 as Roßmann's wingman. They came across 10 enemy aircraft below them, and Hartmann opened full throttle and broke away from Roßmann and engaged the enemy fighters but failed to score any hits, and almost crashed into one. He sped away and later ended crash landed after his plane ran out of fuel. He was subsequently punished, and he was sentenced to three days of working with the ground crew (Patzwall, 2008). Three weeks later he claimed his first "kill" and shot down a 
Soviet Ilyushin Il-2 Sturmovik. By year end he shot down one more plane. By the following April, his tally of kills was 11 planes downed. The ace was on his way to flying history. By August of 1943, he shot down an additional 40 Soviet aircraft (Weal, 2001).

In the same year during the famed Battle of Kursk, Hartmann shot down 4 Soviet planes. Sadly, for him, one of his earlier mentors Krupinski, was shot down and wounded over an airfield. Hartmann took this very personally and he immediately upped his kill rate. In the same battle he continued to claimed five more "kills" on the $7^{\text {th }}$ of July, and four more for each of the following two days (Obermaier, 1989; Bergström, 2007). The Battle of Kursk was the initial time in the Second World War that a German strategic offensive was stopped in its tracks before it could break through enemy fortifications and infiltrate into its strategic areas.

The Luftwaffe's strength on the Eastern Front had started to weaken in 1943 after the debacle of Stalingrad. The Luftwaffe forces in the east were furthermore fatigued and various fighter units were directed back to Germany to defend against the increasing Allied bombing campaigns. By June end, only 38.7 percent of the Luftwaffe's overall aircraft endured in the east (Murray, 1983). In 1943, the Luftwaffe was able to achieve local air superiority and the objective of the Luftwaffe remained unmoved. The precedence of the German air fleet was to increase air superiority, and Hartmann certainly served this cause as best he could. The objective was to detach the battlefield from enemy reinforcements, and to provide close air support (Corum, 1995). Erich Hartmann was so dreaded on the Eastern Front that Soviet planes would do an about-turn and evacuate air space near him, rather than face him and his sublime flying his skills in his daunting Messerschmitt Bf 109.

In the months prior to the battle, VVS formations that were come across exhibited improved training, and were flying better planes with greater skill levels than the Luftwaffe had seen before (Newton, 2002). Yakovlev Yak-9 and Lavochkin La-5 fighters were brought into the fray and provided Soviet pilots a measure of equivalence with the Luftwaffe's planes. Enormous supplies of and enough reserves of replacement aircraft suggested the Red Army and VVS formations would be able to conduct a protracted operation without respite in the force of their exertions (Newton, 2002).

By August 1943, Hartmann's count of destroyed aircraft stood at 42, but this figure more than doubled by the end of that year. In fact, by 1 August 1943 Hartmann turned into an ace-in-a day by claiming 5 kills. He flew 20 missions totaling 18 hours and 29 minutes in six days. Not surprisingly, an additional 7 planes were shot down in the next two days. A supplementary 5 were claimed or destroyed on the $5^{\text {th }}$ of August, a single one was shot down on the $6^{\text {th }}$ August. Another 5 were disposed of on 7 August. On 8 and 9 August Hartmann claimed another 4 kills. Hartmann was unstoppable. However, during an escort mission in August 1943, Hartmann was forced to land due to fragments of wreckage 
from one of his kills hitting his plane. He landed behind enemy lines and Soviet troops apprehended him. He pretended to have internal injuries and was able to flee from his guards after which he walked back to German-held territory and to his unit. This prompted the Soviets to give him the epithet Cherniy Chort (The Black Devil) which also alluded to his immense flying skills and the paint scheme of his aircraft which included a black tulip.

He also pronounced on his capture in his final interview:

“The Russians were attacking in our area and Hrabak gave us our orders. This was in August 1943, and our mission was to support the Stukas of Hans-Ulrich Ruedel in a counterattack. Then things changed. The Red Air Force was bombing German ground positions in support of their offensive, so my flight of eight fighters located and attacked the enemy, about forty Laggs and Yaks with another forty or so Shturmovik ground attack aircraft. I shot down two when something hit my plane. I made a forced landing and was captured by Soviet soldiers. I faked that I was injured as they approached the plane. The believed me and took me to their HQ and their doctor examined me, and he even believed me. They placed me back in the truck (which was German) on a stretcher, and as Stukas made their attacks I rushed the one guard in the truck. He went down and I left out the back. As soon as I did that I heard the truck stop, so I had to keep moving. I found myself in a great field of very tall sunflowers where I tried to hide as I ran, all the while the men chasing me were firing wildly in my direction. I found a small village occupied by Russians and decided to return to the area I had just come from and wait for nightfall. [It was during this time that Mertens took it upon himself to take off and find Hartmann, armed with only a rifle and water, being concerned when his friend had not returned]. I reached my secure area and took a nap, and later I awoke and took off again headed west. I passed a patrol of Russians, about ten I think, so I decided to follow them. Then the patrol disappeared over a small hill, and then there was a firefight. I knew that that must be the German lines since the men of the patrol came flying back over on my side. I then walked to the other side and was challenged by a German sentry who also fired a bullet at me, which ripped open my trouser leg. I was pretty upset, but this man was in complete fear. I was welcomed into their position, given an interrogation and was asked to prepare for contact. Another group of Russians, obviously drunk walked towards our trenches, and the lieutenant gave the order to fire when they came within about twenty meters. They were all destroyed. I was later told that a group of Russians had entered their perimeter speaking fluent German, claiming to be escaped POWs, and when they came in they pulled out some Tommy guns and killed some men. This explained their caution over accepting me on face value, as I had no identification on me. Everything had been taken when I was captured" (Final Interview with Erich Hartmann). 
By 20 September Hartmann had shot down over 100 planes (Spick, 1996) and became one of an elite group of German pilots. The Kursk campaign became a strategic Soviet achievement. A major German offensive had been stopped and the Germans were unable to break through the Soviet defenses. Nonetheless, the Soviet victory was expensive, and they lost far more equipment and forces than the German Army. By October 1943, Hartmann claimed another 35 aerial conquests (Deac, 1998). By 29 October, he had shot down 148 planes and was awarded the Knight's Cross of the Iron Cross (Ritterkreuz des Eisernen Kreuzes). This total soon shot up to 159 kills.

In 1944, Hartmann rapidly bolstered his "kill" total claimed over 50 more Soviet aircraft and all his claims were verified, by pilots flying in his formation (Weal, 2004). He continued to shoot down large numbers of Soviet planes and soon exceeded the previous record of Gunther Rall's 275 kills. Hartmann along with 26 other recipients deservedly received the Iron Cross, the Knight's Cross with Oak Leaves, Swords \& Diamonds, which were usually earmarked for military valour and exemplary leadership.

Hartmann was beckoned to Hitler's military headquarters at Führerhauptquartier Wolfsschanze, close to Rastenburg, to receive the coveted award from Hitler personally. During the encounter, Hartmann discussed at length the inadequacies of German fighter pilot training. Hitler supposedly by his own admission to Hartmann stated that the war was lost and he asserted that he wished the Luftwaffe had more like him (Final Interview with Erich Hartmann).

Hartmann explained:

"When I arrived at the Wolfschanze the world had changed. Hitler had already begun the trials and executions of those involved and everyone was under suspicion. You had to enter three areas of security, and no one was allowed to carry a weapon into the last section. I told Hitler's SS guard to tell the Fuehrer that I would not receive the Diamonds if I were not trusted to carry my Walther pistol. The guy looked like I had just married his mother. He went to speak with von below, who was a Colonel then, and Below came out said it was all right. I hung my cap and pistol belt on the stand and Hitler came to me, and said, "I wish we had more like you and Ruedel", and he gave me the Diamonds, which were encrusted upon another set of Oak Leaves and Swords. We had coffee and lunch, and he confided in me, saying "militarily the war is lost", and that I must already know this, and that if we waited the Western Allies and Soviets would be at war with each other. He also spoke about the partisan problem and he asked me about my experience. Hitler asked me my opinion of the tactics used in fighting the American and British bombers. Since I did not have a lot of experience with this, I simply stated what I thought was a fact. Goering's orders to combat them and the method employed was in error. I also informed him of the deficiencies in pilot training; too many minimally trained men were simply throwing their lives away. He also spoke about the 
new weapons and tactics, and then we parted. That was the last time I saw him, 25 August 1944. I flew back to the unit, where an order for ten days leave waited. I also had to report to Galland, where we discussed the Me-262 situation. I went back to marry my Ushi, that was all that mattered to me" (Final Interview with Erich Hartmann).

On May 8, 1945, when the Germans were getting ready to surrender to the rapidly advancing Allies, Hartmann made his last bold kill. Soviet troops in Brunn, a small town in Eastern Germany were observing a Soviet ace going through his paces with a series of acrobatic manoeuvres. Unexpectedly, Hartmann's ME 109 swept down on it out of the sun. The 20-mm machine gun cannons obliterated the Soviet Yak-9's fuselage. This was Hartmann's concluding kill witnessed by dumbfounded Soviet infantrymen.

\section{The Post War Years}

Once Germany was defeated, Hartmann and his comrades of JG 52, surrendered to United States Army forces and were subsequently handed over to the Red Army. This act was in agreement with the Yalta Agreements, which specified that airmen and soldiers fighting Soviet forces had to surrender directly to them. The Soviets tried to coerce him to offer his services to the communist East German National People's Army, and he was tried on war crimes charges and convicted and ultimately sentenced to 20 years imprisonment, which was later increased to 25 years. He was charged with war crimes, explicitly the "deliberate shooting of 780 Soviet civilians" in the village of Briansk, attacking a "bread factory" on 23 May 1943, and destroying 345 "expensive” Soviet aircraft. He refused to acknowledge the charges and directed his own defence, which the presiding judge criticized as a "waste of time" (Kaplan, 2007).

He spent 10 years in several Soviet prison camps and gulags and was released in 1955. In 1997, the Russian Federation retrospectively relieved him of all charges that were pressed against him and he returned to West Germany where he was inducted into the West German Bundesluftwaffe, assuming the rose to the rank of a colonel.

The world's most fruitful flying ace pilot was now in charge of West Germany's first all-jet fighter squadron, a group of Canadair F-86 Sabres. Hartmann also made numerous trips to the United States, where he was trained on U.S. Air Force planes. He died on 20 September 1993, at the age of 71 in Weil im Schönbuch.

Hartmann, despite being a predator ace pilot, clearly had some endearing opinions:

"One thing I learned is this: Never allow yourself to hate people because of the actions of a few. Hatred and bigotry destroyed my nation, and millions died. I would hope that most people did not hate Germans because of the Nazis, or Americans because of slaves. Never hate, it only eats you alive. 
Keep an open mind and always look for the good in people. You may be surprised at what you find" (Final Interview with Erich Hartmann).

\section{Conclusion}

Hartmann was the most successful fighter ace pilot in the history of aerial warfare. His cumulative 352 kills (350 Soviet and 2 American) over 30 months was incredible given the odds for such a number of "kills". He flew in 1404 combat missions most of which took place on the Eastern Front against the Soviet Union. In the execution of his service to the Luftwaffe and Germany, he was obliged to crash-land his plane 16 times because of mechanical failure or damage sustained by the debris of planes he had just shot down. Matthews and Foreman (2015) have researched the German Federal Archives and found records for 352 aerial victory claims, as well as two further unverified claims. The downed planes include two American P-51 Mustangs, and 350 Soviet Air Force planes shot down on the Eastern Front (Kaplan, 2007). Hartmann deservedly received Germany's highest military decoration. It is doubtful if there will ever be another fighter pilot of the calibre of Erich Hartmann, the ace predator.

\section{Dedication}

This article is dedicated to the memory of the late Sidney Dorrington Hind, born on the $13^{\text {th }}$ of September 1939. Sidney was a keen aviation enthusiast and was well admired among his peers for his vast knowledge of the evolution of aviation, and particularly his knowledge of World War II history. Sidney's fact loving mind informed his captivating history lessons and was topped only by his patience in a continuous pursuit for perfection in recreating aircraft through model building, each detail caringly and accurately constructed through careful research. Sidney finally received a new set of wings on the $5^{\text {th }}$ of January 2016, after a long and hard-fought battle with cancer. Wherever your new wings have taken you, we hope you enjoy this read and we miss your history lessons.

\section{Conflicts of Interest}

The authors declare no conflicts of interest regarding the publication of this paper.

\section{References}

Bader, D. (2004). Fight for the Sky: The Story of the Spitfire and Hurricane. London: Cassell Military Books.

Bell, K. (2017). The Shocking Story of Nazi Germany's Greatest Fighter Ace. The National Interest, War History Network.

Bergström, C. (2007). Kursk-The Air Battle: July 1943. Burgess Hill: Chevron/Ian Allan.

Bungay, S. (2000). The Most Dangerous Enemy: A History of the Battle of Britain. London: Aurum Press.

Caldwell, D. L. (1991). JG 26: Top Guns of the Luftwaffe. New York: Ballantine Books. 
Corum, J. (1995). The Luftwaffe's Army Support Doctrine, 1918-1941. The Journal of Military History, 59, 53-76. https://doi.org/10.2307/2944364

Cynk, J. B. (1998). The Polish Air Force at War: The Official History, 1939-1943. Atglen, PA: Schiffer Publishing.

Deac, W. (1998). Air War's Top Ace. WWII Air War, The Men, The Machines, The Missions. Stamford, CT: Cowles Enthusiast Media.

DeLong, W. (2018). Erich Hartmann: The German World War II Pilot Who Was the Deadliest Flying Ace of All Time, ATI. https://allthatsinteresting.com/erich-hartmann

Delve, K. (2007). The Story of the Spitfire: An Operational and Combat History. London: Greenhill Books.

Donald, D. (2000). Warplanes of the Luftwaffe: Combat Aircraft of Hitler's Luftwaffe 1939-1945. New York: Barnes \& Noble Books.

Duncan Smith, W. G. (1981). Spitfire into Battle. Feltham, Middlesex, UK: Hamlyn Paperbacks.

Final Interview with Erich Hartmann, MIGFLUG. https://migflug.com/jetflights/final-interview-with-erich-hartmann/

Franks, N. L. R. (1994). Sky Tiger-The Story of Sailor Malan. Crecy, Manchester, UK.

Green, W. (1980). Messerschmitt Bf 109: The Augsburg Eagle: A Documentary History. London: Macdonald and Jane's Publishing Group Ltd.

Kaplan, P. (2007). Fighter Aces of the Luftwaffe in World War II. Auldgirth, Dumfriesshire, UK: Pen \& Sword Aviation.

Mason, F. K. (1973). Messerschmitt Bf 109B, C, D, E in Luftwaffe \& Foreign Service. London: Osprey Publishing Limited.

Matthews, A. J., \& Foreman, J. (2015). Luftwaffe Aces-Biographies and Victory ClaimsVolume 2 G-L. Walton on Thames: Red Kite.

Mitcham, S. (2012). Hitler's Commanders: Officers of the Wehrmacht, the Luftwaffe, the Kriegsmarine and the Waffen SS. Lanham, MD: Rowman \& Littlefield.

Murray, W. (1983). Strategy for Defeat: The Luftwaffe, 1933-1945. Montgomery, AL: Air University Press.

Newton, S. (2002). Kursk: The German View. Cambridge: Da Capo Press.

Obermaier, E. (1989). Die Ritterkreuzträger der Luftwaffe Jagdflieger 1939-1945. Mainz, Germany: Verlag Dieter Hoffmann.

Patton, J. (1991). Airpower Journal. V (I). Montgomery, AL: Air University Press.

Patzwall, K. D. (2008). Der Ehrenpokal für besondere Leistung im Luftkrieg Norderstedt. Germany: Verlag.

Price, A. (1991). Spitfire: A Complete Fighting History. Enderby, Leicester, UK: The Promotional Reprint Company Limited.

Price, A. (1995). Late Marque Spitfire Aces 1942-1945. Oxford, UK: Osprey Publishing.

Rall, G. (2007). Mein Flugbuch-Erinnerungen 1938-2006. Moosburg, Germany: NeunundzwanzigSechs Verlag.

Schneekluth, F. (1953). Galland, Adolf, Die Ersten und die Letzten: Jagdflieger im Zweiten Weltkrieg, Munich.

Shores, C. (1983). Air Aces. Greenwich, CT: Bison Books.

Shores, C., \& Williams, C. (1966). Aces High, Neville Spearman, 1966.

Sims, E. H. (1972). Fighter Tactics and Strategy 1914-1970. Fallbrook, CA: Aero Publishers. 
Spick, M. (1983). Fighter Pilot Tactics. Cambridge, UK: Patrick Stephens.

Spick, M. (1996). Luftwaffe Fighter Aces: The Jadgflieger and Their Combat Tactics and Techniques. Barnsley: Pen \& Sword.

Tidy, D. P. (1968). South African Air Aces of World War II. Military History Journal, 1.

Weal, J. (2001). Bf 109 Aces of the Russian Front. Oxford, UK: Osprey Publishing.

Weal, J. (2004). Jagdgeschwader 52: The “Experten”. Oxford, UK: Osprey Publishing.

Wolfe, T. (2001). The Right Stuff. New York: Bantam.

Zaloga, S. J. (2004). Poland 1939: The Birth of Blitzkrieg. Poland: Osprey Publishing. 


\section{Annexure 1. The Record of Hartmann's Kills}

Available online at: https://www.luftwaffe.cz/hartmann.html.

\begin{tabular}{|c|c|c|c|c|c|}
\hline No. & Date & Time & A/C Type & Unit & Location/Comments \\
\hline 1 & 5.11 .1942 & 12:05 & Il-2 & 7./JG 52 & 44,793 at $400 \mathrm{~m}$ \\
\hline 2 & 27.1 .1943 & $11: 30$ & MiG-1 & 7./JG 52 & $15,112:$ at $2.500 \mathrm{~m}$ \\
\hline 3 & 9.2 .1943 & $10: 20$ & LaGG-3 & 7./JG 52 & $86,722:$ at $1.000 \mathrm{~m}$ \\
\hline 4 & 10.2.1943 & $6: 15$ & Boston & 7./JG 52 & $86,671:$ at $3.200 \mathrm{~m}$ \\
\hline 5 & 24.3.1943 & $13: 00$ & Il-2 & 7./JG 52 & $86,712:$ at $20 \mathrm{~m}$ \\
\hline 6 & 27.3.1943 & $11: 50$ & $\mathrm{I}-16$ & 7./JG 52 & $85,171:$ at $800 \mathrm{~m}$ \\
\hline 7 & 15.4.1943 & $15: 33$ & P-39 & 7./JG 52 & $85,192:$ at $200 \mathrm{~m}$ \\
\hline 8 & 26.4.1943 & $11: 35$ & $\mathrm{R}-5$ & 7./JG 52 & $86,722:$ at $700 \mathrm{~m}$ \\
\hline 9 & 28.4.1943 & $9: 30$ & LaGG & 7./JG 52 & $85,122:$ at $5.000 \mathrm{~m}$ \\
\hline 10 & 30.4 .1943 & $16: 00$ & LaGG & 7./JG 52 & $85,712:$ at $4.000 \mathrm{~m}$ \\
\hline 11 & 30.4 .1943 & $16: 20$ & LaGG-3 & 7./JG 52 & $85,752:$ at $4.000 \mathrm{~m}$ \\
\hline 12 & 7.5.1943 & $8: 05$ & LaGG & 7./JG 52 & $75,262:$ at $5.000 \mathrm{~m}$ \\
\hline 13 & 7.5.1943 & $16: 43$ & LaGG & 7./JG 52 & $85,171:$ at $500 \mathrm{~m}$ \\
\hline 14 & 11.5.1943 & $5: 45$ & LaGG & 7./JG 52 & $75,234:$ at $3.000 \mathrm{~m}$ \\
\hline 15 & 11.5.1943 & $5: 50$ & LaGG & 7./JG 52 & $85,144:$ at $5.000 \mathrm{~m}$ \\
\hline 16 & 15.5.1943 & $12: 10$ & $\mathrm{U}-2$ & 7./JG 52 & 86,544: tiefflug \\
\hline 17 & 23.5.1943 & $5: 45$ & LaGG & 7./JG 52 & $85,253:$ at $5.000 \mathrm{~m}$ \\
\hline 18 & 5.7 .1943 & $3: 40$ & Il-2 m.H. & 7./JG 52 & 61,663 at $300 \mathrm{~m}$ \\
\hline 19 & 5.7 .1943 & $7: 10$ & LaGG & 7./JG 52 & 61,151 at $1.500 \mathrm{~m}$ \\
\hline 20 & 5.7 .1943 & 14:00 & IL-2 m.H. & 7./JG 52 & 61,333 at $200 \mathrm{~m}$ \\
\hline 21 & 5.7 .1943 & $18: 15$ & LaGG & 7./JG 52 & 61,124 at $2.000 \mathrm{~m}$ \\
\hline 22 & 7.7.1943 & 3:50 & Il-2 & 7./JG 52 & 61,183: at $500 \mathrm{~m}$ \\
\hline 23 & 7.7.1943 & $3: 52$ & Il-2 & 7./JG 52 & $61,154:$ at $200 \mathrm{~m}$ \\
\hline 24 & 7.7.1943 & $6: 05$ & Il-2 & 7./JG 52 & $61,331:$ at $500 \mathrm{~m}$ \\
\hline 25 & 7.7.1943 & $6: 10$ & LaGG & 7./JG 52 & $61,182:$ at $1.000 \mathrm{~m}$ \\
\hline 26 & 7.7.1943 & $17: 15$ & LaGG & 7./JG 52 & $61,214:$ at $3.000 \mathrm{~m}$ \\
\hline 27 & 7.7.1943 & $17: 20$ & LaGG & 7./JG 52 & $62,873:$ at $2.000 \mathrm{~m}$ \\
\hline 28 & 7.7.1943 & $17: 30$ & LaGG & 7./JG 52 & $62,792:$ at $3.500 \mathrm{~m}$ \\
\hline 29 & 8.7 .1943 & 9:05 & LaGG & 7./JG 52 & $61,223:$ at $2.500 \mathrm{~m}$ \\
\hline 30 & 8.7 .1943 & $9: 10$ & LaGG & 7./JG 52 & $61,221:$ at $2.500 \mathrm{~m}$ \\
\hline 31 & 8.7 .1943 & 18:05 & LaGG & 7./JG 52 & $62,872:$ at $2.500 \mathrm{~m}$ \\
\hline 32 & 8.7 .1943 & $18: 25$ & LaGG & 7./JG 52 & $61,134:$ at $1.000 \mathrm{~m}$ \\
\hline 33 & 9.7 .1943 & $7: 25$ & IL-2 m.H. & 7./JG 52 & $61,272:$ at $500 \mathrm{~m}$ \\
\hline 34 & 9.7 .1943 & $9: 10$ & LaGG & 7./JG 52 & $62,871:$ at $2.000 \mathrm{~m}$ \\
\hline 35 & 9.7 .1943 & $9: 20$ & LaGG & 7./JG 52 & $62,844 \mathrm{~d}:$ at $2.000 \mathrm{~m}$ \\
\hline
\end{tabular}




\section{Continued}

\begin{tabular}{|c|c|c|c|c|c|}
\hline 36 & 10.7.1943 & $7: 05$ & LaGG & 7./JG 52 & $62,872:$ at $2.000 \mathrm{~m}$ \\
\hline 37 & 11.7.1943 & $16: 55$ & LaGG & 7./JG 52 & $62,883:$ at $2.600 \mathrm{~m}$ \\
\hline 38 & 15.7.1943 & $17: 20$ & LaGG & 7./JG 52 & $54,562:$ at $1.500 \mathrm{~m}$ \\
\hline 39 & 16.7.1943 & $14: 15$ & LaGG & 7./JG 52 & $54,661:$ at $1.500 \mathrm{~m}$ \\
\hline 40 & 17.7.1943 & $19: 25$ & LaGG & 7./JG 52 & $54,974:$ at $1.800 \mathrm{~m}$ \\
\hline 41 & 31.7.1943 & 10:00 & LaGG & 7./JG 52 & 54,623: at $1.000 \mathrm{~m}$ \\
\hline 42 & 31.7.1943 & $16: 55$ & LaGG & 7./JG 52 & $64,541:$ at $3.000 \mathrm{~m}$ \\
\hline 43 & 1.8 .1943 & $11: 40$ & LaGG & 7./JG 52 & 64,523 at $4.500 \mathrm{~m}$ \\
\hline 44 & 1.8 .1943 & $14: 40$ & LaGG & 7./JG 52 & 54,663 at $3.000 \mathrm{~m}$ \\
\hline 45 & 1.8 .1943 & $17: 05$ & LaGG & 7./JG 52 & 53,491 at $3.000 \mathrm{~m}$ \\
\hline 46 & 1.8 .1943 & 19:21 & LaGG & 7./JG 52 & 53,131 at $2.000 \mathrm{~m}$ \\
\hline 47 & 1.8 .1943 & $19: 40$ & LaGG & 7./JG 52 & 54,584 at $2.500 \mathrm{~m}$ \\
\hline 48 & 3.8 .1943 & $11: 17$ & LaGG & 7./JG 52 & 61,334 at $1.000 \mathrm{~m}$ \\
\hline 49 & 3.8 .1943 & $11: 22$ & LaGG & 7./JG 52 & 61,412 at $1.000 \mathrm{~m}$ \\
\hline 50 & 3.8 .1943 & $11: 45$ & LaGG & 7./JG 52 & 61,192 at $1.000 \mathrm{~m}$ \\
\hline 51 & 3.8 .1943 & 18:05 & LaGG & 7./JG 52 & 61,193 at $3.000 \mathrm{~m}$ \\
\hline 52 & 4.8.1943 & 10:19 & LaGG & 7./JG 52 & 61,391 at $3.500 \mathrm{~m}$ \\
\hline 53 & 4.8 .1943 & $10: 30$ & LaGG & 7./JG 52 & 61,331 at $2.000 \mathrm{~m}$ \\
\hline 54 & 4.8.1943 & $10: 50$ & $\mathrm{LaGG}$ & 7./JG 52 & 61,334 at $1.000 \mathrm{~m}$ \\
\hline 55 & 4.8.1943 & $13: 43$ & LaGG & 7./JG 52 & 61,343 at $2.500 \mathrm{~m}$ \\
\hline 56 & 4.8 .1943 & $15: 40$ & LaGG & 7./JG 52 & 51,462 at $3.000 \mathrm{~m}$ \\
\hline 57 & 5.8 .1943 & 9:00 & LaGG & 7./JG 52 & 61,351 at $3.000 \mathrm{~m}$ \\
\hline 58 & 5.8 .1943 & $11: 50$ & LaGG & 7./JG 52 & 61,323 at $4.000 \mathrm{~m}$ \\
\hline 59 & 5.8 .1943 & $12: 00$ & LaGG & 7./JG 52 & 61,314 at $3.500 \mathrm{~m}$ \\
\hline 60 & 5.8 .1943 & $17: 04$ & LaGG & 7./JG 52 & 61,333 at $4.000 \mathrm{~m}$ \\
\hline 61 & 5.8 .1943 & $17: 27$ & LaGG & 7./JG 52 & 61,441 at $5.000 \mathrm{~m}$ \\
\hline 62 & 6.8 .1943 & $16: 08$ & LaGG & 7./JG 52 & 61,393 at $3.500 \mathrm{~m}$ \\
\hline 63 & 7.8 .1943 & $8: 30$ & LaGG & 7./JG 52 & 61,391 at $3.000 \mathrm{~m}$ \\
\hline 64 & 7.8 .1943 & $8: 35$ & LaGG & 7./JG 52 & 61,384 at $2.500 \mathrm{~m}$ \\
\hline 65 & 7.8 .1943 & $11: 55$ & $\mathrm{Pe}-2$ & 7./JG 52 & 61,561 at $4.000 \mathrm{~m}$ \\
\hline 66 & 7.8 .1943 & $12: 00$ & LaGG & 7./JG 52 & 61,551 at $3.500 \mathrm{~m}$ \\
\hline 67 & 7.8 .1943 & $12: 20$ & $\mathrm{Pe}-2$ & 7./JG 52 & 61,373 at $2.000 \mathrm{~m}$ \\
\hline 68 & 8.8 .1943 & $7: 15$ & LaGG & 7./JG 52 & 61,572 at $3.000 \mathrm{~m}$ \\
\hline 69 & 8.8 .1943 & $9: 53$ & LaGG & 7./JG 52 & 61,632 at $4.000 \mathrm{~m}$ \\
\hline 70 & 8.8 .1943 & $10: 18$ & LaGG & 7./JG 52 & 61,612 at $3.000 \mathrm{~m}$ \\
\hline 71 & 8.8 .1943 & $12: 54$ & LaGG & 7./JG 52 & 60,253 at $3.000 \mathrm{~m}$ \\
\hline 72 & 9.8 .1943 & $6: 14$ & LaGG & 7./JG 52 & $61,821:$ at $400 \mathrm{~m}$ \\
\hline
\end{tabular}




\section{Continued}

\begin{tabular}{|c|c|c|c|c|c|}
\hline 73 & 9.8 .1943 & 9:30 & LaGG & 7./JG 52 & 61,581 : at $4.000 \mathrm{~m}$ \\
\hline 74 & 9.8 .1943 & $16: 30$ & LaGG & 7./JG 52 & $61,561:$ at $4.000 \mathrm{~m}$ \\
\hline 75 & 9.8 .1943 & $16: 40$ & LaGG & 7./JG 52 & $61,814:$ at $4.500 \mathrm{~m}$ \\
\hline 76 & 12.8 .1943 & $8: 55$ & LaGG & 7./JG 52 & $61,772:$ at $5.000 \mathrm{~m}$ \\
\hline 77 & 15.8 .1943 & 9:14 & $\mathrm{Pe}-2$ & 7./JG 52 & $60,214:$ at $4.500 \mathrm{~m}$ \\
\hline 78 & 15.8 .1943 & $18: 10$ & LaGG & 7./JG 52 & $70,762:$ at $3.000 \mathrm{~m}$ \\
\hline 79 & 17.8 .1943 & $5: 20$ & LaGG & 7./JG 52 & 70,841 : at $4.500 \mathrm{~m}$ \\
\hline 80 & 17.8 .1943 & $12: 30$ & P-39 & 7./JG 52 & $70,791:$ at $2.500 \mathrm{~m}$ \\
\hline 81 & 17.8 .1943 & 13:05 & LaGG & 7./JG 52 & $70,842:$ at $5.000 \mathrm{~m}$ \\
\hline 82 & 17.8 .1943 & $17: 40$ & P-39 & 7./JG 52 & 70,871 : at $3.500 \mathrm{~m}$ \\
\hline 83 & 18.8 .1943 & $10: 00$ & LaGG & 7./JG 52 & $60,193:$ at $3.000 \mathrm{~m}$ \\
\hline 84 & 18.8 .1943 & $12: 45$ & LaGG & 7./JG 52 & 61,792: at $3.000 \mathrm{~m}$ \\
\hline 85 & 18.8 .1943 & $12: 55$ & LaGG & 7./JG 52 & $60,134:$ at $2.000 \mathrm{~m}$ \\
\hline 86 & 19.8 .1943 & $10: 35$ & LaGG & 7./JG 52 & $88,263:$ at $5.000 \mathrm{~m}$ \\
\hline 87 & 19.8 .1943 & $10: 50$ & LaGG & 7./JG 52 & $98,132:$ at $3.500 \mathrm{~m}$ \\
\hline 88 & 19.8 .1943 & $16: 25$ & P-39 & 7./JG 52 & $88,281:$ at $3.000 \mathrm{~m}$ \\
\hline 89 & 20.8 .1943 & $6: 07$ & Il-2 & 7./JG 52 & $88,263:$ at $50 \mathrm{~m}$ \\
\hline 90 & 20.8 .1943 & 6:08 & Il-2 & 7./JG 52 & $88,263:$ at $50 \mathrm{~m}$ \\
\hline 91 & 15.9 .1943 & $12: 20$ & Yak-9 & 9./JG 52 & $68,314:$ at $2.000 \mathrm{~m}$ \\
\hline 92 & 18.9 .1943 & $7: 35$ & LaGG & 9./JG 52 & $69,563:$ at $4.000 \mathrm{~m}$ \\
\hline 93 & 18.9 .1943 & $10: 30$ & LaGG-3 & 9./JG 52 & $68,391:$ at $4.000 \mathrm{~m}$ \\
\hline 94 & 18.9 .1943 & $13: 55$ & LaGG & 9./JG 52 & $68,392:$ at $5.000 \mathrm{~m}$ \\
\hline 95 & 18.9.1943 & $13: 55$ & LaGG & 9./JG 52 & $68,332:$ at $4.000 \mathrm{~m}$ \\
\hline 96 & 19.9.1943 & $14: 40$ & $\mathrm{LaGG}$ & 9./JG 52 & $58,6614:$ at $1.200 \mathrm{~m}$ \\
\hline 97 & 19.9.1943 & $15: 20$ & LaGG & 9./JG 52 & $56,599:$ at $800 \mathrm{~m}$ \\
\hline 98 & 20.9 .1943 & $13: 20$ & LaGG-3 & 9./JG 52 & $59,394:$ at $2.000 \mathrm{~m}$ \\
\hline 99 & 20.9.1943 & $13: 40$ & LaGG & 9./JG 52 & $59,474:$ at $2.000 \mathrm{~m}$ \\
\hline 100 & 20.9.1943 & $15: 35$ & P-39 & 9./JG 52 & $58,682:$ at $6.000 \mathrm{~m}$ \\
\hline 101 & 20.9.1943 & $15: 50$ & $\mathrm{LaGG}$ & 9./JG 52 & $58,334:$ at $2.000 \mathrm{~m}$ \\
\hline 102 & 25.9 .1943 & $7: 55$ & LaGG & 9./JG 52 & $58,532:$ at $3.000 \mathrm{~m}$ \\
\hline 103 & 25.9.1943 & $12: 43$ & LaGG & 9./JG 52 & $58,831:$ at $5.000 \mathrm{~m}$ \\
\hline 104 & 25.9 .1943 & $16: 35$ & LaGG & 9./JG 52 & 58,611: at $4.000 \mathrm{~m}$ \\
\hline 105 & 26.9.1943 & $6: 55$ & LaGG & 9./JG 52 & 58,691 : at $5.000 \mathrm{~m}$ \\
\hline 106 & 26.9.1943 & $7: 05$ & P-39 & 9./JG 52 & $58,554:$ at $600 \mathrm{~m}$ \\
\hline 107 & 26.9.1943 & $9: 55$ & P-39 & 9./JG 52 & $58,592:$ at $6.000 \mathrm{~m}$ \\
\hline 108 & 27.9.1943 & $11: 15$ & LaGG & 9./JG 52 & 58,611: at $4.600 \mathrm{~m}$ \\
\hline 109 & 27.9.1943 & $11: 25$ & LaGG & 9./JG 52 & $58,643:$ at $3.000 \mathrm{~m}$ \\
\hline
\end{tabular}




\section{Continued}

\begin{tabular}{|c|c|c|c|c|c|}
\hline 110 & 28.9 .1943 & $16: 30$ & LaGG & 9./JG 52 & $58,641:$ at $2.000 \mathrm{~m}$ \\
\hline 111 & 29.9.1943 & $6: 56$ & LaGG & 9./JG 52 & $58,644:$ at $4.000 \mathrm{~m}$ \\
\hline 112 & 29.9.1943 & $8: 55$ & P-39 & 9./JG 52 & $58,682:$ at $4.000 \mathrm{~m}$ \\
\hline 113 & 30.9 .1943 & $6: 55$ & LaGG & 9./JG 52 & $58,681:$ at $4.500 \mathrm{~m}$ \\
\hline 114 & 30.9 .1943 & $14: 30$ & P-39 & 9./JG 52 & $58,732:$ at $2.500 \mathrm{~m}$ \\
\hline 115 & 30.9 .1943 & $16: 40$ & P-39 & 9./JG 52 & $58,583:$ at $5.500 \mathrm{~m}$ \\
\hline 116 & 1.10 .1943 & $12: 20$ & LaGG & 9./JG 52 & 58,641 at $5.000 \mathrm{~m}$ \\
\hline 117 & 1.10 .1943 & $12: 30$ & LaGG & 9./JG 52 & 58,762 at $3.500 \mathrm{~m}$ \\
\hline 118 & 2.10 .1943 & $8: 40$ & LaGG & 9./JG 52 & 58,833 at $5.000 \mathrm{~m}$ \\
\hline 119 & 2.10 .1943 & $8: 50$ & $\mathrm{Pe}-2$ & 9./JG 52 & 58,762 at $6.500 \mathrm{~m}$ \\
\hline 120 & 2.10 .1943 & $11: 40$ & P-39 & 9./JG 52 & 58,851 at $5.000 \mathrm{~m}$ \\
\hline 121 & 2.10 .1943 & $13: 55$ & LaGG & 9./JG 52 & 58,672 at $4.000 \mathrm{~m}$ \\
\hline 122 & 3.10 .1943 & $10: 10$ & LaGG & 9./JG 52 & $58,592:$ at $3.500 \mathrm{~m}$ \\
\hline 123 & 3.10 .1943 & $16: 05$ & LaGG & 9./JG 52 & 58,591 at $2.000 \mathrm{~m}$ \\
\hline 124 & 4.10 .1943 & $7: 25$ & P-39 & 9./JG 52 & 58,614 at $5.000 \mathrm{~m}$ \\
\hline 125 & 11.10 .1943 & $13: 40$ & LaGG & 9./JG 52 & $58,124:$ at $2.000 \mathrm{~m}$ \\
\hline 126 & 12.10 .1943 & $7: 00$ & LaGG & 9./JG 52 & $58,134:$ at $1.500 \mathrm{~m}$ \\
\hline 127 & 12.10 .1943 & $7: 15$ & LaGG & 9./JG 52 & $58,241:$ at $2.000 \mathrm{~m}$ \\
\hline 128 & 12.10 .1943 & $7: 35$ & $\mathrm{LaGG}$ & 9./JG 52 & $58,211:$ at $1.000 \mathrm{~m}$ \\
\hline 129 & 12.10 .1943 & $15: 00$ & LaGG & 9./JG 52 & $58,161:$ at $1.000 \mathrm{~m}$ \\
\hline 130 & 13.10 .1943 & $10: 35$ & LaGG & 9./JG 52 & $58,181:$ at $3.000 \mathrm{~m}$ \\
\hline 131 & 14.10 .1943 & $8: 20$ & LaGG & 9./JG 52 & $58,184:$ at $4.000 \mathrm{~m}$ \\
\hline 132 & 14.10 .1943 & $8: 25$ & LaGG & 9./JG 52 & $58,151:$ at $3.500 \mathrm{~m}$ \\
\hline 133 & 14.10 .1943 & $15: 20$ & LaGG & 9./JG 52 & $58,153:$ at $3.000 \mathrm{~m}$ \\
\hline 134 & 15.10 .1943 & $8: 59$ & LaGG & 9./JG 52 & $58,153:$ at $4.000 \mathrm{~m}$ \\
\hline 135 & 15.10 .1943 & 9:05 & LaGG & 9./JG 52 & $58,154:$ at $4.000 \mathrm{~m}$ \\
\hline 136 & 15.10 .1943 & $11: 50$ & LaGG & 9./JG 52 & $58,181:$ at $4.000 \mathrm{~m}$ \\
\hline 137 & 20.10 .1943 & $7: 15$ & P-39 & 9./JG 52 & $39,472:$ at $4.000 \mathrm{~m}$ \\
\hline 138 & 20.10 .1943 & $7: 20$ & P-39 & 9./JG 52 & $39,393:$ at $3.500 \mathrm{~m}$ \\
\hline 139 & 20.10 .1943 & $14: 42$ & P-39 & 9./JG 52 & $39,534:$ at $1.500 \mathrm{~m}$ \\
\hline 140 & 21.10 .1943 & $7: 40$ & LaGG & 9./JG 52 & $39,481:$ at $4.500 \mathrm{~m}$ \\
\hline 141 & 24.10 .1943 & $14: 10$ & LaGG & 9./JG 52 & $57,753:$ at $2.000 \mathrm{~m}$ \\
\hline 142 & 24.10 .1943 & $14: 35$ & P-39 & 9./JG 52 & $58,534:$ at $3.500 \mathrm{~m}$ \\
\hline 143 & 25.10 .1943 & 10:00 & $\mathrm{Pe}-2$ & 9./JG 52 & $49,523:$ at $6.500 \mathrm{~m}$ \\
\hline 144 & 25.10 .1943 & $15: 30$ & LaGG & 9./JG 52 & $57,182:$ at $2.000 \mathrm{~m}$ \\
\hline 145 & 26.10 .1943 & 8:08 & P-39 & 9./JG 52 & $57,181:$ at $4.000 \mathrm{~m}$ \\
\hline 146 & 26.10 .1943 & $8: 15$ & P-39 & 9./JG 52 & $57,153:$ at $4.500 \mathrm{~m}$ \\
\hline
\end{tabular}




\section{Continued}

\begin{tabular}{|c|c|c|c|c|c|}
\hline 147 & 29.10 .1943 & $8: 50$ & LaGG & 9./JG 52 & $38,151:$ at $5.500 \mathrm{~m}$ \\
\hline 148 & 29.10 .1943 & 11:05 & P-39 & 9./JG 52 & 29,499: at $2.000 \mathrm{~m}$ \\
\hline 149 & 7.12 .1943 & $13: 46$ & LaGG & 9./JG 52 & SSE Dneprovka: $4.000 \mathrm{~m}$ \\
\hline 150 & 13.12 .1943 & $10: 10$ & LaGG & 9./JG 52 & S Jsnigirevka: at $900 \mathrm{~m}$ \\
\hline 151 & 15.12 .1943 & $12: 32$ & LaGG & 9./JG 52 & NW Chervonovershka: at $800 \mathrm{~m}$ \\
\hline 152 & 15.12 .1943 & $12: 45$ & LaGG & 9./JG 52 & N Verblyuzhka: at $700 \mathrm{~m}$ \\
\hline 153 & 15.12 .1943 & $14: 16$ & LaGG & 9./JG 52 & NNE Chervonovershka: at $900 \mathrm{~m}$ \\
\hline 154 & 17.12 .1943 & $14: 10$ & LaGG & 9./JG 52 & E Novgorotka: at $5.000 \mathrm{~m}$ \\
\hline 155 & 17.12 .1943 & $14: 20$ & P-39 & 9./JG 52 & NE Novgorotka: at $4.000 \mathrm{~m}$ \\
\hline 156 & 17.12 .1943 & $14: 24$ & P-39 & 9./JG 52 & S Verblyuzhka: at $4.000 \mathrm{~m}$ \\
\hline 157 & 20.12 .1943 & 9:02 & LaGG & 9./JG 52 & NE Verchniy: at $200 \mathrm{~m}$ \\
\hline 158 & 20.12 .1943 & $12: 13$ & LaGG & 9./JG 52 & W Tomakovka: at $250 \mathrm{~m}$ \\
\hline 159 & 20.12 .1943 & $12: 13$ & LaGG & 9./JG 52 & NW Verchniy: at $200 \mathrm{~m}$ \\
\hline 160 & 3.1 .1944 & $12: 10$ & LaGG-3 & 9./JG 52 & 38,893 at $1.000 \mathrm{~m}$ [Novo Krasnoye] \\
\hline 161 & 7.1.1944 & $14: 20$ & LaGG-3 & 9./JG 52 & 29,361 at $4.000 \mathrm{~m}$ \\
\hline 162 & 7.1.1944 & $14: 25$ & LaGG-3 & 9./JG 52 & 29,344 at $3.000 \mathrm{~m}$ \\
\hline 163 & 8.1 .1944 & $14: 15$ & P-39 & 9./JG 52 & 29,371 at $3.500 \mathrm{~m}$ \\
\hline 164 & 8.1 .1944 & $14: 20$ & P-39 & 9./JG 52 & 29,352 at $3.000 \mathrm{~m}$ \\
\hline 165 & 8.1 .1944 & $14: 30$ & P-39 & 9./JG 52 & 29,552 at $4.000 \mathrm{~m}$ \\
\hline 166 & 16.1.1944 & $10: 15$ & P-39 & 9./JG 52 & 29,343 at $3.500 \mathrm{~m}$ \\
\hline 167 & 16.1.1944 & $10: 26$ & LaGG & 9./JG 52 & 19,464 at $4.000 \mathrm{~m}$ \\
\hline 168 & 16.1.1944 & $10: 47$ & LaGG & 9./JG 52 & 19,492 at $4.000 \mathrm{~m}$ \\
\hline 169 & 17.1.1944 & $9: 44$ & LaGG & 9./JG 52 & 29,512 at $3.000 \mathrm{~m}$ \\
\hline 170 & 17.1.1944 & $12: 19$ & LaGG & 9./JG 52 & 29,521 at $2.500 \mathrm{~m}$ \\
\hline 171 & 17.1.1944 & $12: 24$ & $\mathrm{Pe}-2$ & 9./JG 52 & 19,492 at $1.000 \mathrm{~m}$ \\
\hline 172 & 17.1.1944 & 14:06 & LaGG & 9./JG 52 & 29,341 at $4.000 \mathrm{~m}$ \\
\hline 173 & 23.1.1944 & $11: 30$ & LaGG & 9./JG 52 & 29,342 at $3.000 \mathrm{~m}$ \\
\hline 174 & 23.1.1944 & $13: 20$ & LaGG & 9./JG 52 & 19,262 at $1.000 \mathrm{~m}$ \\
\hline 175 & 23.1.1944 & $13: 25$ & LaGG & 9./JG 52 & 19,264 at $1.000 \mathrm{~m}$ \\
\hline 176 & 23.1.1944 & $13: 45$ & LaGG & 9./JG 52 & 19,293 at $1.000 \mathrm{~m}$ \\
\hline 177 & 24.1 .1944 & $10: 25$ & LaGG-3 & 9./JG 52 & 19,262 at $2.000 \mathrm{~m}$ \\
\hline 178 & 30.1 .1944 & $10: 05$ & LaGG & 9./JG 52 & 19,274 at $400 \mathrm{~m}$ \\
\hline 179 & 30.1 .1944 & $10: 10$ & LaGG & 9./JG 52 & 19,283 at $300 \mathrm{~m}$ \\
\hline 180 & 30.1 .1944 & $12: 25$ & LaGG & 9./JG 52 & 19,241 at $4.000 \mathrm{~m}$ \\
\hline 181 & 30.1 .1944 & $12: 30$ & LaGG & 9./JG 52 & 19,243 at $3.000 \mathrm{~m}$ \\
\hline 182 & 30.1 .1944 & $14: 25$ & LaGG & 9./JG 52 & 19,261 at $2.000 \mathrm{~m}$ \\
\hline 183 & 30.1 .1944 & $14: 30$ & LaGG & 9./JG 52 & 19,432 at $2.300 \mathrm{~m}$ \\
\hline
\end{tabular}




\section{Continued}

\begin{tabular}{|c|c|c|c|c|c|}
\hline 184 & 31.1 .1944 & 11:10 & LaGG & 9./JG 52 & 19,241 at $2.000 \mathrm{~m}$ \\
\hline 185 & 31.1 .1944 & 11:15 & LaGG & 9./JG 52 & 19,132 at $1.200 \mathrm{~m}$ \\
\hline 186 & 1.2 .1944 & $8: 10$ & LaGG & 9./JG 52 & 19,284 at $800 \mathrm{~m}$ \\
\hline 187 & 1.2 .1944 & 10:00 & LaGG & 9./JG 52 & 19,162 at $2.500 \mathrm{~m}$ \\
\hline 188 & 1.2 .1944 & 10:05 & LaGG & 9./JG 52 & 19,241 at $2.000 \mathrm{~m}$ \\
\hline 189 & 1.2 .1944 & 12:00 & LaGG & 9./JG 52 & 19,124 at $1.500 \mathrm{~m}$ \\
\hline 190 & 1.2 .1944 & 12:02 & LaGG & 9./JG 52 & 19,134 at $1.000 \mathrm{~m}$ \\
\hline 191 & 3.2 .1944 & 13:40 & LaGG & 9./JG 52 & 19,152 at $400 \mathrm{~m}$ \\
\hline 192 & 4.2 .1944 & $11: 40$ & P-39 & 9./JG 52 & 10,783 at $3.500 \mathrm{~m}$ \\
\hline 193 & 26.2 .1944 & $9: 08$ & P-39 & 9./JG 52 & 29,381: at $3.000 \mathrm{~m}$ \\
\hline 194 & 26.2 .1944 & $9: 16$ & P-39 & 9./JG 52 & 29,384: at $3.000 \mathrm{~m}$ \\
\hline 195 & 26.2.1944 & $11: 45$ & P-39 & 9./JG 52 & 29,524: at $4.000 \mathrm{~m}$ \\
\hline 196 & 26.2.1944 & 11:48 & P-39 & 9./JG 52 & 29,521: at $3.000 \mathrm{~m}$ \\
\hline 197 & 26.2 .1944 & $11: 53$ & P-39 & 9./JG 52 & 29,514: at $3.000 \mathrm{~m}$ \\
\hline 198 & 26.2 .1944 & $11: 58$ & P-39 & 9./JG 52 & 29,524: at $2.500 \mathrm{~m}$ \\
\hline 199 & 26.2.1944 & $12: 03$ & P-39 & 9./JG 52 & 29,524: at $2.000 \mathrm{~m}$ \\
\hline 200 & 26.2.1944 & $14: 40$ & P-39 & 9./JG 52 & 29,552: at $2.500 \mathrm{~m}$ \\
\hline 201 & 26.2 .1944 & $14: 45$ & P-39 & 9./JG 52 & 29,531: at $3.000 \mathrm{~m}$ \\
\hline 202 & 26.2.1944 & $14: 50$ & P-39 & 9./JG 52 & 29,512: at $2.000 \mathrm{~m}$ \\
\hline 203 & 23.4.1944 & $15: 45$ & LaGG & 9./JG 52 & $35,351:$ at $1.500 \mathrm{~m}$ \\
\hline 204 & 24.4.1944 & $11: 55$ & LaGG & 9./JG 52 & $35,474:$ at $2.000 \mathrm{~m}$ \\
\hline 205 & 24.4.1944 & $12: 15$ & P-39 & 9./JG 52 & $35,472:$ at $5.000 \mathrm{~m}$ \\
\hline 206 & 26.4.1944 & $14: 15$ & P-39 & 9./JG 52 & $35,474:$ at $4.000 \mathrm{~m}$ \\
\hline 207 & 26.4.1944 & $14: 20$ & P-39 & 9./JG 52 & $35,481:$ at $4.000 \mathrm{~m}$ \\
\hline 208 & 3.5 .1944 & $15: 45$ & LaGG & 9./JG 52 & $35,273:$ at $2.000 \mathrm{~m}$ \\
\hline 209 & 4.5.1944 & $16: 10$ & LaGG & 9./JG 52 & $35,424:$ at $3.500 \mathrm{~m}$ \\
\hline 210 & 4.5.1944 & $17: 35$ & LaGG & 9./JG 52 & $35,424:$ at $5.000 \mathrm{~m}$ \\
\hline 211 & 4.5.1944 & $17: 50$ & LaGG & 9./JG 52 & $35,214:$ at $2.500 \mathrm{~m}$ \\
\hline 212 & 5.5 .1944 & $8: 20$ & LaGG & 9./JG 52 & $35,421:$ at $3.000 \mathrm{~m}$ \\
\hline 213 & 5.5 .1944 & $10: 45$ & LaGG & 9./JG 52 & $85,614:$ at $2.000 \mathrm{~m}$ \\
\hline 214 & 5.5 .1944 & 10:48 & LaGG & 9./JG 52 & $35,612:$ at $2.000 \mathrm{~m}$ \\
\hline 215 & 5.5 .1944 & $10: 54$ & LaGG & 9./JG 52 & 35,532: at $1.500 \mathrm{~m}$ \\
\hline 216 & 5.5 .1944 & $14: 15$ & LaGG & 9./JG 52 & $35,274:$ at $1.500 \mathrm{~m}$ \\
\hline 217 & 5.5 .1944 & $14: 15$ & LaGG & 9./JG 52 & 35,423: at $4.500 \mathrm{~m}$ \\
\hline 218 & 6.5 .1944 & $10: 45$ & LaGG & 9./JG 52 & $35,442:$ at $2.500 \mathrm{~m}$ \\
\hline 219 & 7.5.1944 & $9: 22$ & P-39 & 9./JG 52 & $35,644:$ at $5.000 \mathrm{~m}$ \\
\hline 220 & 7.5.1944 & $9: 30$ & P-39 & 9./JG 52 & $35,641:$ at $5.000 \mathrm{~m}$ \\
\hline
\end{tabular}




\section{Continued}

\begin{tabular}{|c|c|c|c|c|c|}
\hline 221 & 7.5.1944 & $9: 40$ & P-39 & 9./JG 52 & $35,483:$ at $3.500 \mathrm{~m}$ \\
\hline 222 & 8.5 .1944 & $9: 25$ & LaGG & 9./JG 52 & $35,612:$ at $1.000 \mathrm{~m}$ \\
\hline 223 & 8.5 .1944 & $13: 45$ & LaGG & 9./JG 52 & $35,362:$ at $4.000 \mathrm{~m}$ \\
\hline 224 & 20.5.1944 & $12: 24$ & LaGG-5 & 9./JG 52 & $98,754:$ at $2.500 \mathrm{~m}$ \\
\hline 225 & 20.5.1944 & $18: 35$ & LaGG-5 & 9./JG 52 & $98,711:$ at $2.000 \mathrm{~m}$ \\
\hline 226 & 29.5.1944 & $15: 35$ & P-39 & 9./JG 52 & $78,764 \mathrm{~L}$ tiefst \\
\hline 227 & 30.5 .1944 & $11: 25$ & P-39 & 9./JG 52 & $78,644:$ at $3.500 \mathrm{~m}$ \\
\hline 228 & 30.5.1944 & $14: 38$ & P-39 & 9./JG 52 & $78,613:$ at $4.000 \mathrm{~m}$ \\
\hline 229 & 31.5.1944 & 18:05 & P-39 & 9./JG 52 & $78,647:$ at $4.000 \mathrm{~m}$ \\
\hline 230 & 31.5.1944 & 18:08 & P-39 & 9./JG 52 & $78,614:$ at $5.000 \mathrm{~m}$ \\
\hline 231 & 31.5.1944 & $18: 13$ & P-39 & 9./JG 52 & $78,733:$ at $3.500 \mathrm{~m}$ \\
\hline 232 & 1.6 .1944 & $11: 31$ & LaGG & 9./JG 52 & $78,677:$ at $200 \mathrm{~m}$ \\
\hline 233 & 1.6 .1944 & $11: 32$ & LaGG & 9./JG 52 & $78,813:$ at $2.000 \mathrm{~m}$ \\
\hline 234 & 1.6 .1944 & $14: 20$ & LaGG & 9./JG 52 & $78,648:$ at $2.000 \mathrm{~m}$ \\
\hline 235 & 1.6 .1944 & $14: 30$ & LaGG & 9./JG 52 & $78,673:$ at $1.000 \mathrm{~m}$ \\
\hline 236 & 1.6 .1944 & $14: 32$ & P-39 & 9./JG 52 & $78,673:$ at $2.000 \mathrm{~m}$ \\
\hline 237 & 1.6 .1944 & $14: 35$ & LaGG & 9./JG 52 & $78,675:$ at $1.000 \mathrm{~m}$ \\
\hline 238 & 2.6.1944 & $17: 10$ & P-39 & 9./JG 52 & $78,685:$ at $4.000 \mathrm{~m}$ \\
\hline 239 & 2.6.1944 & $17: 15$ & P-39 & 9./JG 52 & $78,640:$ at $4.000 \mathrm{~m}$ \\
\hline 240 & 3.6.1944 & $13: 30$ & P-39 & 9./JG 52 & $78,825:$ at $4.000 \mathrm{~m}$ \\
\hline 241 & 3.6.1944 & $13: 33$ & P-39 & 9./JG 52 & $78,813:$ at $3.000 \mathrm{~m}$ \\
\hline 242 & 3.6.1944 & 14:00 & LaGG & 9./JG 52 & 78,733: at $500 \mathrm{~m}$ \\
\hline 243 & 3.6.1944 & $16: 17$ & LaGG & 9./JG 52 & $78,568:$ at $600 \mathrm{~m}$ \\
\hline 244 & 4.6.1944 & $15: 10$ & P-39 & 9./JG 52 & 78,733: at $1.500 \mathrm{~m}$ \\
\hline 245 & 4.6.1944 & $15: 25$ & LaGG & 9./JG 52 & $78,595:$ at $200 \mathrm{~m}$ \\
\hline 246 & 4.6.1944 & $17: 13$ & P-39 & 9./JG 52 & 78,596: at $2.000 \mathrm{~m}$ \\
\hline 247 & 4.6.1944 & $17: 23$ & P-39 & 9./JG 52 & $78,591:$ at $2.500 \mathrm{~m}$ \\
\hline 248 & 4.6.1944 & $17: 53$ & P-39 & 9./JG 52 & $78,590:$ at $2.000 \mathrm{~m}$ \\
\hline 249 & 4.6.1944 & 18:15 & P-39 & 9./JG 52 & $78,565:$ at $2.000 \mathrm{~m}$ \\
\hline 250 & 4.6.1944 & $18: 18$ & P-39 & 9./JG 52 & $78,560:$ at $2.000 \mathrm{~m}$ \\
\hline 251 & 5.6 .1944 & $13: 12$ & P-39 & 9./JG 52 & $25 \mathrm{~km}$ NW Jasi: at $5.000 \mathrm{~m}$ \\
\hline 252 & 5.6 .1944 & 13:19 & P-39 & 9./JG 52 & $5 \mathrm{~km} \mathrm{~W}$ Jasi: at $5.000 \mathrm{~m}$ \\
\hline 253 & 5.6.1944 & $15: 20$ & LaGG & 9./JG 52 & $78,582:$ at $3.500 \mathrm{~m}$ \\
\hline 254 & 5.6.1944 & $17: 10$ & LaGG & 9./JG 52 & $78,722:$ at $100 \mathrm{~m}$ \\
\hline 255 & 5.6 .1944 & 18:07 & LaGG & 9./JG 52 & $78,562:$ at $2.500 \mathrm{~m}$ \\
\hline 256 & 5.6 .1944 & $18: 35$ & P-39 & 9./JG 52 & $78,674:$ at $5.000 \mathrm{~m}$ \\
\hline 257 & 5.6 .1944 & $18: 43$ & P-39 & 9./JG 52 & $78,583:$ at $4.000 \mathrm{~m}$ \\
\hline
\end{tabular}




\section{Continued}

\begin{tabular}{|c|c|c|c|c|c|}
\hline 258 & 6.6.1944 & $15: 25$ & LaGG & 9./JG 52 & $78,598:$ at $600 \mathrm{~m}$ \\
\hline 259 & 6.6 .1944 & $15: 30$ & LaGG & 9./JG 52 & 78,591: at $1.000 \mathrm{~m}$ \\
\hline 260 & 6.6 .1944 & 19:15 & P-39 & 9./JG 52 & $78,582:$ at $1.500 \mathrm{~m}$ \\
\hline 261 & 6.6 .1944 & $19: 25$ & P-39 & 9./JG 52 & $78,569:$ at $1.000 \mathrm{~m}$ \\
\hline 262 & 6.6 .1944 & 19:35 & P-39 & 9./JG 52 & $78,728:$ at $800 \mathrm{~m}$ \\
\hline 263 & 12.6 .1944 & 14:00 & P-39 & 9./JG 52 & $78,862:$ at $1.500 \mathrm{~m}$ \\
\hline 264 & 12.6 .1944 & 14:05 & P-39 & 9./JG 52 & $78,831:$ at $3.000 \mathrm{~m}$ \\
\hline 265 & 24.6.1944 & $9: 50$ & Mustang & 9./JG 52 & $65,136:$ at $3.000 \mathrm{~m}$ \\
\hline 266 & 27.6.1944 & 18:10 & LaGG & 9./JG 52 & $85,229:$ at $3.000 \mathrm{~m}$ \\
\hline 267 & 27.6.1944 & $18: 15$ & LaGG & 9./JG 52 & $85,245:$ at $2.000 \mathrm{~m}$ \\
\hline 268 & 1.7 .1944 & $17: 30$ & LaGG & 9./JG 52 & $94,173:$ at $4.000 \mathrm{~m}$ \\
\hline 269 & 1.7 .1944 & $17: 32$ & LaGG & 9./JG 52 & $94,179:$ at $3.000 \mathrm{~m}$ \\
\hline 270 & 15.8 .1944 & 11:43 & LaGG-5 & 9./JG 52 & 01,633 at $1.500 \mathrm{~m}$ \\
\hline 271 & 15.8.1944 & $11: 45$ & LaGG & 9./JG 52 & 01,663 at $1.500 \mathrm{~m}$ \\
\hline 272 & 17.8.1944 & $12: 25$ & P-39 & 9./JG 52 & 11,267 at $3.000 \mathrm{~m}$ \\
\hline 273 & 17.8 .1944 & $12: 30$ & P-39 & 9./JG 52 & 11,273 at $5.000 \mathrm{~m}$ \\
\hline 274 & 17.8 .1944 & $15: 27$ & LaGG & 9./JG 52 & 11,277 at $800 \mathrm{~m}$ \\
\hline 275 & 18.8 .1944 & $16: 27$ & LaGG & 9./JG 52 & 11,272 at $500 \mathrm{~m}$ \\
\hline 276 & 20.8 .1944 & 12:00 & LaGG & 9./JG 52 & 11,779 at $1.500 \mathrm{~m}$ \\
\hline 277 & 20.8 .1944 & 12:03 & LaGG & 9./JG 52 & 11,757 at $1.200 \mathrm{~m}$ \\
\hline 278 & 20.8 .1944 & $12: 10$ & LaGG & 9./JG 52 & 11,724 at $1.200 \mathrm{~m}$ \\
\hline 279 & 22.8 .1944 & $12: 20$ & P-39 & 9./JG 52 & $11,274:$ at $3.000 \mathrm{~m}$ \\
\hline 280 & 22.8.1944 & $12: 30$ & P-39 & 9./JG 52 & $11,335:$ at $2.000 \mathrm{~m}$ \\
\hline 281 & 22.8.1944 & $12: 31$ & P-39 & 9./JG 52 & $11,339:$ at $2.000 \mathrm{~m}$ \\
\hline 282 & 22.8 .1944 & $15: 17$ & P-39 & 9./JG 52 & $11,411:$ at $2.000 \mathrm{~m}$ \\
\hline 283 & 22.8 .1944 & $15: 22$ & P-39 & 9./JG 52 & $11,271:$ at $1.500 \mathrm{~m}$ \\
\hline 284 & 23.8.1944 & $14: 15$ & LaGG & 9./JG 52 & 11,411: at $1.000 \mathrm{~m}$ \\
\hline 285 & 23.8.1944 & $14: 18$ & LaGG & 9./JG 52 & 11,413: at $1.200 \mathrm{~m}$ \\
\hline 286 & 23.8 .1944 & $14: 20$ & LaGG & 9./JG 52 & 11,278: at $1.000 \mathrm{~m}$ \\
\hline 287 & 23.8.1944 & $17: 10$ & LaGG & 9./JG 52 & $11,363:$ at $1.500 \mathrm{~m}$ \\
\hline 288 & 23.8 .1944 & $17: 12$ & LaGG & 9./JG 52 & $11,333:$ at $1.500 \mathrm{~m}$ \\
\hline 289 & 23.8.1944 & $17: 15$ & LaGG & 9./JG 52 & 11,412: at $1.200 \mathrm{~m}$ \\
\hline 290 & 23.8.1944 & $17: 17$ & LaGG & 9./JG 52 & $11,421:$ at $1.000 \mathrm{~m}$ \\
\hline 291 & 23.8.1944 & $17: 30$ & LaGG & 9./JG 52 & $11,444:$ at $3.500 \mathrm{~m}$ \\
\hline 292 & 24.8.1944 & 13:15 & LaGG & 9./JG 52 & $11,417:$ at $1.500 \mathrm{~m}$ \\
\hline 293 & 24.8.1944 & 13:18 & LaGG & 9./JG 52 & $11,416:$ at $2.000 \mathrm{~m}$ \\
\hline 294 & 24.8.1944 & 13:19 & LaGG & 9./JG 52 & $11,421:$ at $1.200 \mathrm{~m}$ \\
\hline
\end{tabular}




\section{Continued}

\begin{tabular}{|c|c|c|c|c|c|}
\hline 295 & 24.8.1944 & $13: 25$ & LaGG & 9./JG 52 & $11,427:$ at $1.500 \mathrm{~m}$ \\
\hline 296 & 24.8.1944 & $13: 27$ & LaGG & 9./JG 52 & $11,419:$ at $1.000 \mathrm{~m}$ \\
\hline 297 & 24.8.1944 & $13: 40$ & P-39 & 9./JG 52 & 11,443: at $3.000 \mathrm{~m}$ \\
\hline 298 & 24.8.1944 & $16: 00$ & LaGG-5 & 9./JG 52 & 11,335 : at $1.500 \mathrm{~m}$ \\
\hline 299 & 24.8.1944 & $16: 03$ & LaGG-5 & 9./JG 52 & 11,363 : at $1.200 \mathrm{~m}$ \\
\hline 300 & 24.8.1944 & $16: 06$ & P-39 & 9./JG 52 & $11,447:$ at $1.200 \mathrm{~m}$ \\
\hline 301 & 24.8.1944 & $16: 10$ & P-39 & 9./JG 52 & $11,441:$ at $1.000 \mathrm{~m}$ \\
\hline 302 & 24.8.1944 & $16: 20$ & LaGG & 9./JG 52 & 11,422: no height \\
\hline 303 & 25.8 .1944 & $13: 27$ & LaGG & 9./JG 52 & 1663: at $200 \mathrm{~m}$ \\
\hline 304 & 27.8.1944 & 18:00 & P-39 & 9./JG 52 & $11,353:$ at $2.500 \mathrm{~m}$ \\
\hline 305 & 27.10 .1944 & $10: 16$ & Yak-9 & 4./JG 52 & $18,265:$ at $2.500 \mathrm{~m}$ \\
\hline 306 & 31.10 .1944 & $15: 30$ & Yak-7 & 4./JG 52 & 98,799 \\
\hline $307 ?$ & 1.11 .1944 & $14: 35$ & LaGG-5 & 4./JG 52 & $98,836:$ at $2.500 \mathrm{~m}$ \\
\hline $307 ?$ & 7.11 .1944 & $13: 35$ & Yak-7 & 4./JG 52 & $98,563:$ at $1.000 \mathrm{~m}$ \\
\hline 308 & 13.11 .1944 & $14: 10$ & Yak-9 & 4./JG 52 & 89 ---: at $5.000 \mathrm{~m}$ \\
\hline 309 & 13.11 .1944 & $14: 15$ & Yak-9 & 4./JG 52 & 9866-: at $4.200 \mathrm{~m}$ \\
\hline 310 & 13.11 .1944 & $14: 25$ & Yak-9 & 4./JG 52 & 0854-: at $4.000 \mathrm{~m}$ \\
\hline 311 & 13.11 .1944 & $14: 30$ & Yak-9 & 4./JG 52 & $98,637:$ at $4.000 \mathrm{~m}$ \\
\hline 312 & 14.11 .1944 & $11: 35$ & LaGG-5 & 4./JG 52 & $98,494:$ at $2.000 \mathrm{~m}$ \\
\hline 313 & 14.11 .1944 & $11: 45$ & LaGG-5 & 4./JG 52 & $08,471:$ at $800 \mathrm{~m}$ \\
\hline 314 & 16.11 .1944 & $8: 45$ & Yak-9 & 4./JG 52 & $98,368:$ at $4.000 \mathrm{~m}$ \\
\hline 315 & 16.11 .1944 & $8: 50$ & Yak-9 & 4./JG 52 & 98,487: at $1.000 \mathrm{~m}$ \\
\hline 316 & 17.11 .1944 & $14: 25$ & Boston III & 4./JG 52 & $98,584:$ at $2.000 \mathrm{~m}$ \\
\hline 317 & 22.11 .1944 & $11: 40$ & Yak-9 & 4./JG 52 & $98,453:$ at $3.500 \mathrm{~m}$ \\
\hline 318 & 22.11 .1944 & 11:45 & La-5 & 4./JG 52 & 98,452: at $4.500 \mathrm{~m}$ \\
\hline 319 & 22.11 .1944 & - & $\mathrm{Il}-2$ & 4./JG 52 & - \\
\hline 320 & 22.11 .1944 & - & $\mathrm{Il}-2$ & 4./JG 52 & - \\
\hline 321 & 22.11 .1944 & - & $\mathrm{Il}-2$ & 4./JG 52 & - \\
\hline 322 & 22.11 .1944 & - & Yak-3 & 4./JG 52 & - \\
\hline 323 & 23.11 .1944 & - & Yak-3 & 4./JG 52 & - \\
\hline 324 & 23.11 .1944 & - & Yak-9 & 4./JG 52 & - \\
\hline 325 & 23.11 .1944 & - & Yak-9 & 4./JG 52 & - \\
\hline 326 & 23.11 .1944 & - & Yak-9 & 4./JG 52 & - \\
\hline 327 & 23.11 .1944 & - & Yak-9 & 4./JG 52 & - \\
\hline 328 & 5.12 .1944 & $13: 20$ & LaGG-5 & 4./JG 52 & 98,419: at $1.200 \mathrm{~m}$ \\
\hline 329 & 5.12 .1944 & $13: 25$ & LaGG-5 & 4./JG 52 & 98,278: at $1.000 \mathrm{~m}$ \\
\hline 330 & 9.12 .1944 & $13: 10$ & Yak-9 & 4./JG 52 & 88,683 : at $2.000 \mathrm{~m}$ \\
\hline
\end{tabular}




\section{Continued}

\begin{tabular}{|c|c|c|c|c|c|}
\hline 331 & 9.12 .1944 & $13: 20$ & Yak-9 & 4./JG 52 & $88,694:$ at $2.000 \mathrm{~m}$ \\
\hline 332 & I.-II.1945 & - & Yak-9 & Stab I./JG 52 & - \\
\hline 333 & I.-II.1945 & - & Yak-9 & Stab I./JG 52 & - \\
\hline 334 & I.-II.1945 & - & Il-2 & Stab I./JG 52 & - \\
\hline 335 & I.-II.1945 & - & Boston III & Stab I./JG 52 & or Mitchell \\
\hline 336 & I.-II.1945 & - & Il-2 & Stab I./JG 52 & - \\
\hline 337 & 4.2 .1945 & - & Yak-9 & Stab I./JG 53 & - \\
\hline 338 & 20.2.1945 & - & La-5 & Stab I./JG 52 & - \\
\hline 339 & 20.2.1945 & - & P-39 & Stab I./JG 52 & - \\
\hline 340 & 6.3 .1945 & - & La-5 & Stab I./JG 52 & - \\
\hline 341 & 6.3 .1945 & - & Yak-9 & Stab I./JG 52 & - \\
\hline 342 & 7.3.1945 & - & Yak-9 & Stab I./JG 52 & - \\
\hline 343 & 7.3.1945 & - & Yak-9 & Stab I./JG 52 & - \\
\hline 344 & 9.3 .1945 & - & Yak-9 & Stab I./JG 52 & - \\
\hline 345 & 11.3.1945 & - & Yak-9 & Stab I./JG 52 & - \\
\hline 346 & 16.3 .1945 & - & $\mathrm{E} / \mathrm{a}$ & Stab I./JG 52 & - \\
\hline 347 & ??.3.1945 & - & Mustang & Stab I./JG 52 & - \\
\hline 348 & 10.4 .1945 & - & B-26 & Stab I./JG 52 & - \\
\hline 349 & 11.4 .1945 & - & Yak-3 & Stab I./JG 52 & - \\
\hline 350 & 17.4.1945 & - & Yak-9 & Stab I./JG 52 & - \\
\hline 351 & 25.4 .1945 & - & P-39 & Stab I./JG 52 & - \\
\hline 352 & 8.5 .1945 & $8: 30-9: 20$ & Yak-9 & Stab I./JG 52 & Brün area: at $4000 \mathrm{~m}$ \\
\hline
\end{tabular}

